\title{
COVID-19: Communication Strategies during the Pandemic
}

\author{
Serena Camilla Crocchi
}

University of Florence, Italy

\begin{abstract}
The profound cultural and communicational changes brought by internet and social media platforms in the last two decades have had major repercussion in the conceptualization of the world of information and many of its dynamics. In the last decade we have a conspicuous crescent amount of scientific literature focused on social media environments and, consequently, many new fields of application and research studies have spread. Social media platforms possess an accessible democratic nature that opens to everyone the territories once controlled by the mass media, official sources of political parties, organizations, and governmental institutions. In this article we will explore some of these peculiar dynamics and phenomena examining how social media have been involved by and have contributed to constructing the social imaginary and the conceptual frame of the current global pandemic caused by Coronavirus. We will also analyze the use of the war metaphor made by many politicians referring to COVID-19 in order to shape public understanding. We also aim to demonstrate that structural changes in communication, made possible by the digital dimension of social media together with the narrative-subjective approach to the facts have undermined the epistemological basis of truth as a realistic representation of the world.
\end{abstract}

Keywords: communication, COVID-19, fake news, infodemic, post-truth

\section{Introduction}

The disruptive revolution brought by internet and social media platforms in the that opens to everyone the territories once lead by the mass media, official sources of political parties, organizations, and governmental institutions. In this article we will explore some of these peculiar dynamics and phenomena examining how social media have been last two decades have had major reper- cussion in the conceptualization of the world of information and many of its dynamics. In the last decade we have a conspicuous crescent amount of scientific literature focused on social media environments and, consequently, many new fields of applica- tion and research studies have spread. Social media platforms possess an accessible democratic nature involved by and have contributed to constructing the theoretical frame of the current global pandemic caused by Coronavirus (COVID19, from now on). In terms of Communication Crisis theories and Communication Management, we will consider five main aspects of the nature of this event that have shaped the communicative dimension, considering two traditional approaches to formal validity - i.e., semantics/meaning, in terms of semantic clauses and truth preservation, and syntactic organization, in terms of rules of inference and the availability of proofs. the aspects that we will consider are the primary role of social media in the construction of meaning and topics about the virus, the changes in media consumption during the pandemic, the changes in crises communication management brought by social media, the spread of fake news and misinformation fostered by the new information environment and some of the communicative framing emerged during the pandemic. At the time of this writing, about six months have passed from the first cases inside Chinese territories and about three months have passed since the declaration of lockdown in many European countries including UK.

At the end of December 2019, Chinese authorities alerted the World Health Organization (WHO, from now on) of pneumonia cases in Wuhan City, located in the Hubei province. The cause was unknown, and the disease was first referred to as 2019-nCoV and then named COVID-19. Two days later, the Huanan market was closed because it was suspected to be the source of the disease, since some of the patient presenting with the illness worked there. The disease has spread quickly throughout China, and then to the rest of the world. The virus has so far spread

*Corresponding author: serenacamilla.crocchi@unifi.it

(c) TIIKM Publishing 
throughout all the inhabited continents and affected millions of people, killing thousands of them. Many workers are now working from remote; schools have been shut down, kids are at home, locked down in their houses. They can leave only for reasons of primary neces- sity, such as shopping for groceries and going to medical appointments. With many countries implementing lock downs and promoting quarantines, suggesting, or forcing citizens to stay inside their homes to avoid spreading the virus, millions of people are experiencing a global pandemic for the first time in their lives and as mentioned before, some of the peculiarity of this event emerged in communicative responses COVID-19 is the official name for the coro- navirus disease 2019 (Wicke and Bolognesi 2020). The disease is caused by the SARS-CoV-2 coronavirus, which had not previously been identified in humans. More than eleven million cases have been confirmed globally, and the death toll has passed 525,000 . Countries around the world have now started to relax lockdown restrictions but are being urged to continue widespread testing. The pandemic has put health systems under severe strain, and there have been shortages of critical supplies. There is currently no treatment for the disease, and research teams around the world have joined the race to develop a safe and effective vaccine. The spread of COVID-19 has severely impacted the global economy as well. These are incredibly uncertain times for the financial markets, with countries around the world suffering the destabilizing effects of the pandemic. No company is immune to the challenges, and the repercussions of the health crisis are expected to be felt for many more months. According to Wicke and Bolognesi:

The social distancing enforced by various governments stimulated many internet users to use social media to communicate and express their own concerns, opinions, ideas, and feelings in relation to this new situation. On Twitter, for example, around $16 \mathrm{~K}$ Tweets are posted by Twitter users every hour, containing a hashtag such as \#coronavirus, \#Covid-19 or \#COVID. A variety of issues are debated daily on Twitter, in relation to the pandemic. these include the political and social consequences of various governmental decisions, the situations in the hospitals getting increasingly more crowded every day, the interpretation of the numbers associated with the spreading of the pandemic, the problems that families face with home-schooling their children while working from home, and so forth. Among these issues, the discussion around the treatment and containment of the virus is surely a central topic. (Wicke and Bolognesi, 2020, p. 3)

\section{A Global Disease in a Globalized World}

Living in a globalized world where time and space are relative concepts, borders do not exist, interactions are very fast, and distances are cancelled means having great power, but this power also hides a dangerous pitfall. Internetbased technologies have changed the way in which human beings live. the so called Fourth Industrial Revolution affected humans' everyday lives and dramatically changed their behaviours in real life and furthermore in communications. The internet has revolutionized the computer and communications world like nothing before. The invention of the telegraph, telephone, radio, and computer set the stage for this unprecedent- ed integration of capabilities. The internet is at once a world-wide broadcasting medium, a mechanism for information dissemination, and a medium for interaction and collaboration between individuals and their computers without regard for geographic location. (Crocchi, 2019) the astonishing success of social media platforms such as Facebook and Twitter led us to this discussion and to the aims of this paper.

Communication during the COVID-19 has been greatly affected by the socio-economic dynamics and social movements typical of a liquid society as intended by Zygmunt Bauman (2000). Starting from the postmodern, his philosophical and sociological speculation, opens - through the analysis of the phenomenon of globalization - to the meta-level of life, and then circumscribes the most recent thinking on political life, until reaching the liquid modernity: overcoming postmodernity itself. As a result individual, society, ethics, power, religion become those words impregnated with a liquidity capable of condensing in itself the most significant aspects of the present reality: a dimension in which the lasting gives way to the transient, the need to the desire, and the necessity to the utility. Zygmunt Bauman is one of the greatest interpreters of our present time, a time which turns into a shapeless 
mass tending to a constant and relentless change. This is not the modern era, nor the postmodern one, if anything, this period can be well identified as liquid modernity: a concept, able to focus on the transformations that affect human life concerning the general policy determinations of life. Moreover, Bauman's liquid modernity is a term that can overcome the concept of postmodernism, because basically leaning towards the contemporary world: the reality in which life considers highly what is transitory rather than permanent, the immediate rather than long term; and regards utility as prior to any other value. Consequently, it is fundamental to understand in advance and profoundly the concept of liquidity around which Bauman interweaves his most recent philosophical and sociological reflection. Solidity and liquidity are the distinctive features of two eras: modernity and postmodernity, which becomes liquid modernity as it relates to con- temporary existence (Palese, 2013).

In recent years, large-scale communication has undergone profound technological structural changes, with the emergence of what has been called 'mass-self communication', based on horizontal multi-directional and interactive communication networks. Thanks to wireless communication system, social platforms are prevalent today and almost everywhere. The Digital 2020 edition of the annual reports published in partnership with We Are Social and Hootsuite shows that digital, mobile, and social media have become an indispensable part of everyday life for people all over the world. More than 4.5 billion people are using the internet at the start of 2020 , while social media users have passed the 3.8 billion mark. Nearly 60 percent of the world's population is already online, and the latest trends suggest that more than half of the world's total population will use social media by the middle of this year. Some important challenges remain, however, and there is still work to do to ensure that everyone around the world has fair and equal access to life-changing digital connectivity.

Digital's role in our lives has reached new heights, with an increasing number of people spending more time doing many things online than ever before: the number of people around the world using the internet has grown to 4.54 billion, an increase of 7 percent (298 million new users) compared to January 2019. Worldwide, there are 3.80 billion social media users in January 2020, with this number increasing by more than 9 percent (321 million new users) since this time last year. Globally, more than 5.19 billion people now use mobile phones, with user numbers up by 124 million ( 2.4 percent) over the past year. In addition to this global phenomenon, the number of internet users in Italy increased by 1.2 million $(+2.4 \%)$ between 2019 and 2020 and there were 35.00 million social media users in January 2020. the internet is also playing an ever more important role in our lives. With the world's internet users spending an average of 6 hours and 43 minutes online each day, the typical user now spends more than 40 percent of their working life (Kemp, 2020).

The pervasive presence of digital communication and the double public/personal dimension as interaction tool play a crucial role within current social network movements since communication technologies are now at the root of social movements. As largely demonstrated by the birth and spread of many social movements in the last fiftheen years, such as the Arabic Spring in Egypt (2011), the Indignados in Spain (2011), Occupy Wall Street (2010), Gezi Park protests in Turkey (2013), Movimento Cinque Stelle in Italy (2009), Me Too (2017) and Black Lives Matter (2020), digital communication plays a primary role in the formation and practice of social movements. the point is that citizens can challenge rulers only by connecting with each other, sharing the indignation, feeling united, and building alternative projects for themselves and for the society in general (Castells, 2014, p. 217). In a world clouded by the economic crisis, political cynicism, cultural void and individual discouragement, the internet and social media offer a limitless perspective. Many politicians were exposed as corrupt and liars. Financial gurus went from being the object of general envy to the target of universal contempt. Many governments were put under attack and mass-media were suspected. Trust in the institutions had disappeared and consequentially some individuals had found themselves together (on the internet) in search of new forms of identity, values, and symbols to believe in. Everything started from social networks, on the Internet the autonomy spaces are largely outside control of governments and corporations that historically had always held control and monopolized communication channels to assert their power. These movements spread by contagion in a networked world, centered on the wireless Internet, and marked by rapid and viral diffusion of images and ideas (Castells, 2014). Another effect of globalization is the growth in the geographical extension, interconnection, 
and speed of information and communications technologies. Manuel Castells identifies globalization as "the rise of the network society", characterized by the binomial of connected versus not connected (Castells, 1996). This new binomial redefines the meaning of the concepts of identity, belonging, inclusion, sovereignty, and citizenship. the increasing interdependence among global systems implies a dark side involving previously unimagined threats: environmental disasters with a global impact like the Chernobyl accident and the British Petroleum oil spill off the US coast in 2010; the rapid, global spread of dis- eases like SARS, avian influenza, mad cow disease, and COVID-19; and the growth of illegal networks engaged in drug dealing, money laundering, the weapons trade, and international terrorism (Maddalena and Gili, 2020).

the fall of the giants (political parties, academics, and scientists) the crumbling of granite knowledge and trust in institutions entails a potentially dangerous paradigmatic change in which scientific and academic authority are depleted of their own value and even mocked because hopelessly misunderstood. In a liquid, interconnected and very fast society in which 'one is worth one' it is equally easy to get lost and lose the sense of reality with respect to important issues. The opinions of the common man have the same epistemological weight and communicative value of the scientist.

\section{.Infodemic and media consumption during COVID-19}

\section{Dealing with the infodemic}

The term infodemic was coined in 2003 by journalist and political scientist David Roth- kopf in a Washington Post column, when the world's attention was on the current crisis's less terrifying relation:

SARS is the story of not one epidemic but two, and the second epidemic, the one that has largely escaped the headlines, has implications that are far greater than the disease itself. That is because it is not the viral epidemic but rather an "information epidemic" that has transformed SARS, or severe acute respiratory syndrome, from a bungled Chinese regional health crisis into a global economic and social debacle. The information epidemic - or infodemic - has made the public health crisis harder to control and contain ${ }^{1}$. (Rothkopf, 2003)

The term has seen renewed usage in the time of COVID-19. It is a blend of information and epidemic that typically refers to a rapid and far-reaching spread of both accurate and in- accurate information about something, such as a disease. As facts, rumors, and fears mix and disperse, it becomes difficult to learn essential information about an issue. Rothkopf goes on to clarify what he means by the word:

What exactly do I mean by the infodemic? A few facts, mixed with fear, speculation, and rumor, amplified, and relayed swithly worldwide by modern information technologies, have affected national and international economies, politics and even security in ways that are utterly disproportionate with the root realities. It is a phenomenon we have seen with greater frequency in recent years - not only in our reaction to SARS, for example, but also in our response to terrorism and even to relatively minor occurrences such as shark sightings. (Rothkopf, 2003)

In February 2020 WHO launched a platform aimed to combat misinformation around COVID-19. In fact, as stated by the WHO, the COVID-19 outbreak and response has been accompanied by a massive infodemic: an overabundance of information that makes it difficult for people to find trustworthy sources and reliable guidance

${ }^{1}$ washingtonpost.com/archive/opinions/2003/05/11/when-the-buzz-bites-back/bc8cd84f-cab6-4648-bf580277261af6cd/(06/2020). 
when they need $\mathrm{it}^{2}$. Infodemic refers to a large increase in the volume of information associated with a specific topic and whose growth can occur exponentially in a short period of time due to a specific incident, such as the current pandemic. In this situation, misinformation and rumours appear on the scene, along with manipulation of information with doubtful intent. In the information age, this phenomenon is amplified through social networks, spreading farther and faster like a virus. Misinformation is false or inaccurate information deliberately intended to deceive. In the context of the current pandemic, it can greatly affect all aspects of life, specifically people's mental health, since searching for COVID-19 updates on the Internet has jumped 50\%-70\% across all generations ${ }^{3}$. Misinformation in a pandemic can negatively affect human health. Many false or misleading stories are fabricated and shared without any background or quality checking. Much of this misinformation is based on conspiracy theories, some introducing elements of these into seemingly mainstream discourse. Inaccurate and false information has been circulating about all aspects of the disease: how the virus originated, its cause, its treatment, and its mechanism of spread. Misinformation can circulate and be absorbed very quickly, changing people's behaviour, and potentially leading them to take greater risks. These phenomena make the pandemic much more severe, harming more people and jeopardizing the reach and sustainability of the global health system. Increased global access to cell phones with an Internet connection, as well as social media, has led to the exponential production of information and the number of possible paths for getting it, creating an information epidemic.

Trough social media an unprecedented amount of information is being produced and shared to every corner of the world, reaching billions of people, and contributing to misinformation which expands at the same pace as content production and distribution paths grow. Therefore, the very same infodemic accelerates and perpetuates misinformation creating a never-ending cycle. According to a study by the Centre for Health Informatics at the University of Illinois, in the month of March around 550 million tweets included the terms coronavirus, corona virus, covid19, covid-19, covid_19 or pandemic. An exponential increase in the volume of tweets occurred around the start of the lockdown in Italy, reaching a plateau around the day the United States declared the pandemic had become a national emergency. Of the total tweets, 35\% came from the United States, followed by the United Kingdom (7\%), Brazil (6\%), Spain (5\%), and India (4\%). the gender distribution was almost even, with men tweeting a little more (55\%). the most-used pandemic-related hashtags were \#Pandemic and \#FlattentheCurve.

Table1. Proportion concerned about what is real and what is fake on the internet when it comes to news - all markets (Reuters Institute) ${ }^{4}$

2"We're not just fighting an epidemic; we're fighting an infodemic", said WHO Director-General Tedros Adhanom Ghebreyesus at the Munich Security Conference on Feb 15.

${ }^{3}$ Pan American Health Organization, 2020.

${ }^{4}$ The author has personally reworked the graphs using the data provided by the appropriately cited companies. 


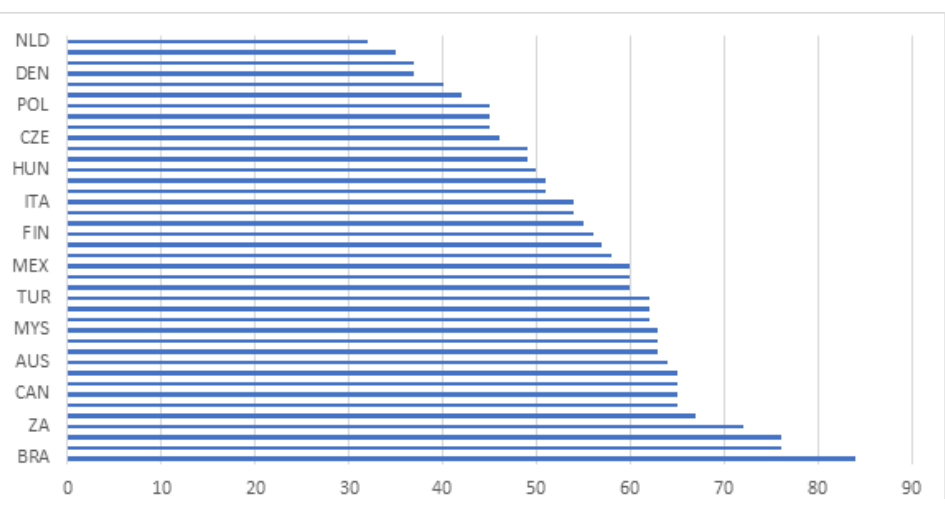

More than half $(55 \%)$ of the sample across 38 countries remains concerned about their ability to separate what is real and fake on the internet. Concern is highest in Brazil (85\%), South Africa (70\%), Mexico (68\%), and France $(67 \%)$, and lowest in the Netherlands (31\%), and Germany (38\%), which tend to be less polarized politically. The biggest jump in concern came in the UK (70\%) where the news media have taken a lead in breaking stories about mis- information on Facebook and YouTube and there has been a high-profile House of Commons inquiry into the issue (Reuters Institute, 2019).

\section{Changes in media consumption during COVID-19}

A global survey conducted in March 2020 by Statista.com revealed that the coronavirus has had a direct impact on in-home media consumption around the world, with 35 percent of total respondents professing to have read more books or listened to more audiobooks at home and 18 percent having listened to more radio due to the COVID-19 pandemic, whilst more than 40 percent of consumers spent longer on messaging services and social media. Interestingly, although at least 50 percent of respondents in most countries said that they were watching more news coverage, figures for Australia and the United States were lower, amounting to just 42 and 43 percent, respectively. Australians were also the least likely to be reading more newspapers; just five percent of consumers said that they were doing so compared to the global total of 14 percent. Whilst 60 percent of Italians were spending longer on messaging services, in Japan the same was true for only eight percent of respondents, and survey participants from China and the Philippines were by far the most likely to be spending more time on music streaming services. 
Table 2. Consuming media at home due to the coronavirus worldwide 2020, by country (Statista.com)

\begin{tabular}{|c|c|c|c|c|c|c|c|c|c|c|c|c|c|c|c|}
\hline & $\begin{array}{l}\text { World- } \\
\text { wide }\end{array}$ & Italy & Spain & France & Germany & China & U.S. & U.K. & $\begin{array}{l}\text { Singa- } \\
\text { pore }\end{array}$ & Australia & Brazil & 1Japan I & $\begin{array}{l}\text { Philippine } \\
\text { s }\end{array}$ & $\begin{array}{l}\text { South } \\
\text { Africa }\end{array}$ & In $\%$ \\
\hline $\begin{array}{l}\text { Watching } \\
\text { more news } \\
\text { coverage }\end{array}$ & 67 & 67 & 63 & 50 & 60 & 77 & 43 & 50 & 57 & 42 & 69 & 56 & 79 & 61 & $\%$ \\
\hline $\begin{array}{l}\text { Watching } \\
\text { more } \\
\text { shows/films } \\
\text { on streaming } \\
\text { services }\end{array}$ & 51 & 53 & 58 & 31 & 21 & 63 & 42 & 32 & 35 & 30 & 43 & 21 & 61 & 39 & $\%$ \\
\hline $\begin{array}{l}\text { Watching } \\
\text { more TV } \\
\text { on broadcast } \\
\text { channels }\end{array}$ & 45 & 55 & 43 & 53 & 35 & 46 & 42 & 32 & 32 & 32 & 43 & 51 & 70 & 46 & $\%$ \\
\hline $\begin{array}{l}\text { Spending } \\
\text { longer on } \\
\text { messaging } \\
\text { services }\end{array}$ & 45 & 60 & 61 & 24 & 22 & 59 & 17 & 24 & 35 & 19 & 48 & 8 & 55 & 45 & $\%$ \\
\hline $\begin{array}{l}\text { Spending } \\
\text { longer on } \\
\text { social media }\end{array}$ & 44 & 52 & 49 & 27 & 21 & 50 & 32 & 21 & 39 & 28 & 50 & 23 & 71 & 44 & $\%$ \\
\hline $\begin{array}{l}\text { Spending } \\
\text { more time } \\
\text { on computer/ } \\
\text { video games }\end{array}$ & 36 & 41 & 48 & 39 & 21 & 29 & 29 & 20 & 25 & 24 & 41 & 32 & 40 & 32 & $\%$ \\
\hline
\end{tabular}

\begin{tabular}{|l|l|l|l|l|l|l|l|l|l|l|l|l|l|l|l|}
\hline $\begin{array}{l}\text { Reading more } \\
\text { books/liste- ning } \\
\text { to more } \\
\text { audiobooks }\end{array}$ & 35 & 36 & 42 & 24 & 19 & 44 & 25 & 19 & 18 & 16 & 27 & 18 & 27 & 26 & $\%$ \\
\hline $\begin{array}{l}\text { Listening to } \\
\text { more strea- } \\
\text { ming services }\end{array}$ & 35 & 25 & 27 & 14 & 13 & 49 & 18 & 14 & 17 & 16 & 30 & 11 & 43 & 22 & $\%$ \\
\hline $\begin{array}{l}\text { Listening to } \\
\text { more radio }\end{array}$ & 18 & 29 & 32 & 23 & 24 & 16 & 16 & 17 & 20 & 15 & 18 & 9 & 32 & 36 & $\%$ \\
\hline $\begin{array}{l}\text { Reading more } \\
\text { magazines }\end{array}$ & 16 & 23 & 22 & 14 & 17 & 14 & 12 & 15 & 29 & 14 & 22 & 16 & 23 & 24 & $\%$ \\
\hline $\begin{array}{l}\text { Reading more } \\
\text { newspapers }\end{array}$ & 14 & 18 & 14 & 14 & 10 & 17 & 12 & 9 & 9 & 5 & 12 & 7 & 12 & 11 \\
\hline $\begin{array}{l}\text { Creating/ } \\
\text { uploading } \\
\text { videos }\end{array}$
\end{tabular}




\begin{tabular}{|l|l|l|l|l|l|l|l|l|l|l|l|l|l|l|l|l|}
\hline $\begin{array}{l}\text { Listening to } \\
\text { more podcasts }\end{array}$ & 12 & 8 & 10 & 6 & 6 & 13 & 10 & 11 & 9 & 11 & 15 & 4 & 17 & 13 & $\%$ \\
\hline
\end{tabular}

During lockdown, not only media consumption increased greatly overall, but the main re- searches and discussions concerned the virus and the pandemic. According to a study conducted by Statista.com in March 2020, the most used sources of news and information regarding the coronavirus among news consumers worldwide were major news organizations, with 64 percent of respondents saying that they got most of their information about the virus from larger news companies. The study also showed that social media was a popular news source for COVID-19 updates in several countries around the world. Despite social networking sites being the least trusted media source worldwide, for many consumers social media was a more popular source of information for updates on the coronavirus pandemic than global health organizations like the WHO or National health authorities like the CDC, particularly in Japan, South Africa, and Brazil. Government sources also varied in popularity among consumers in different parts of the world. Whilst 63 percent of Italian respondents relied mostly on national government sources, just 22 percent of UK news consumers did the same, preferring to get their updates from larger organizations. Similarly, twice as many Italians used local government sources to keep up to date than adults in the United Kingdom, and U.S. consumers were also less likely to rely on news from the government.

Table 3. Most used sources of reliable news and information for updates on the coronavirus worldwide as of March 2020, by country (Statista, 2020)

\begin{tabular}{|l|l|l|l|l|l|l|l|l|l|l|l|l|}
\hline & Total & Japan & $\begin{array}{l}\text { South } \\
\text { Korea }\end{array}$ & $\begin{array}{l}\text { South } \\
\text { Africa }\end{array}$ & $\begin{array}{l}\text { United } \\
\text { Kingdom }\end{array}$ & Canada & Germany & $\begin{array}{l}\text { United } \\
\text { States }\end{array}$ & Brazil & Italy & France & In \% \\
\hline $\begin{array}{l}\text { Major news } \\
\text { organizations }\end{array}$ & 64 & 73 & 73 & 67 & 67 & 66 & 65 & 63 & 59 & 55 & 52 & $\%$ \\
\hline $\begin{array}{l}\text { National } \\
\text { government } \\
\text { sources }\end{array}$ & 40 & 41 & 50 & 36 & 34 & 31 & 32 & 25 & 40 & 63 & 45 & $\%$ \\
\hline Social media & 38 & 44 & 35 & 72 & 22 & 33 & 26 & 26 & 64 & 32 & 21 & $\%$ \\
\hline $\begin{array}{l}\text { Global health } \\
\text { organizations } \\
\text { like the WHO }\end{array}$ & 34 & 22 & 18 & 43 & 36 & 45 & 30 & 27 & 46 & 46 & 36 & $\%$ \\
\hline $\begin{array}{l}\text { National health } \\
\text { authorities } \\
\text { like the CDC }\end{array}$ & 29 & 15 & 25 & 28 & 37 & 41 & 18 & 45 & 25 & 36 & 20 & $\%$ \\
\hline $\begin{array}{l}\text { Friends and } \\
\text { family }\end{array}$ & 27 & 36 & 34 & 44 & 20 & 22 & 25 & 22 & 30 & 20 & 21 & $\%$ \\
\hline $\begin{array}{l}\text { Local } \\
\text { government } \\
\text { sources }\end{array}$ & 26 & 27 & 29 & 28 & 15 & 27 & 27 & 20 & 31 & 33 & 21 & $\%$ \\
\hline
\end{tabular}

\section{Communication Crisis Management and Social Media}

\section{Communication Crisis}

Over the past two decades, the spread of the internet and social media has changed human reality and perception in many ways. Communication was at the centre of a paradigmatic revolution that disrupted previous knowledge, consumer habits, work habits and the way of doing politics. Here we would like to briefly recall how the 
consequences of these new socio-economic dynamics have had a great impact on communication theories and, in this case above all, on crisis communication management. the word crisis derived from the Greek word кpí 1 , 'judgement', 'result of a trial', 'turning point', 'selection', 'decision' (according to Thucydides), but also 'contention' or 'quarrel' (according to Plato), a standard, from which to derive criterion, 'means for judging', but also 'ability to discern', and critical, 'suitable to judge', 'crucial', 'decisive' as well as pertaining to the art of judgement (Bauman and Bordoni, 2014, p.2). According to Coombs (2009), it is possible to conceptualize the phenomenon of the crisis by drawing on various definitions that consider the possible predictive nature of this phenomenon and the importance of the perception by the public towards it. Among many definitions, we will consider Coombs's updated definition of crisis in communication as 'an unpredictable event that threatens important expectancies of stakeholders and can seriously impact an organization's performance and generate negative outcomes' (Coombs, 2015, p.3). The definition emphasizes stakeholders' role in co-creating the meaning of a crisis as meaning is socially constructed and crises are no exception. Thus, it was important to utilize a definition that reflects the perceptual nature of crises. Over the last couple of decades, much of the academic literature has addressed the crisis, disaster, and risk communication, among which crisis communication is organizational and public relations focused. As Coombs stated (2015), the many definitions of crisis communication can be categorized into two types: one is to define the crisis as an event; the other is to regard the crisis as part of a process. As mentioned previously in this paragraph, we will adopt Coomb's most recent definition which considers crisis as an event. As a result, by coding crises as events, it is possible to identify directly the name of a crisis and analyse variables such as types of crises and the time of crisis events, which serve as important dimensions to provide a holistic examination of the nature of a crisis (Pearson and Mitroff, 1993). According to his definition, Coombs observed that we can segment and appropriately research and develop crisis planning in three phases: pre-crisis (signal detection, prevention and preparation), crisis event (recognition and containment) and post-crisis (evaluation, learning and follow-up communication). Pre-crisis involves efforts to prevent crises and to prepare for crisis management. Crisis is the response to an actual event. Post-crisis are efforts to learn from the crisis event (Coombs, 2015). These three categories reflect the phases of crisis management. They are useful because they provide a mechanism for considering the breadth of crisis communication. As a matter of fact - more than any other communicative process - crisis communication is rhetorical, it requires advocacy both in process and in meaning. Crisis discourse is propositional therefore it entails the development of fact-based, evaluation-driven and policy conclusions. Indeed, facts do not actually count as much as how they are framed and interpreted.

\section{How Social Media impact on Communication Crisis Theories}

Defined as "a group of Internet-based applications that build on the ideological and technological foundations of Web 2.0" (Kaplan and Haenlein, 2010, p. 61), the types of social media such as Wikipedia, Twitter, Facebook and Pinterest are ushering in a new era of crisis communication between the organizations, political parties, institutions and their public. These new technologies offer pros and cons when it comes to crisis: organizations can efficiently utilize social media to interact with the massive and diverse stakeholders but - nevertheless - with the emergence and exchange of user-generated contents, social media create a breeding ground for crises or risks. In fact, Studies of 16 international companies (e.g., the United States, China, France, Germany,and Mexico) found that $36 \%$ of crises were caused by digital security failures or negative new media publicities (Chen, 2016). By incorporating social media strategies into the traditional framework of crisis communication strategies, according to Chen three main questions might emerge:

With the increasing use of social media, what crisis communication strategies may be applied to manage socialmediated events? How would the organizations apply CCS in different phases of crises? Have new strategies ever emerged and substituted the traditional CCS spectrum? (Chen, 2016, p.4) 
These questions have solicited numerous discussions among scholars. To explore the patterns of the use of crisis responses, Coombs started developing in 1995 the Situational Crisis Communication theory (SCT, from now on). Originated and developed from the Image Restoration theory (IRT) which emphasized CCS as symbolic resources, SCCT included the attribution theory and developed situation-oriented CCS based on experimental studies. However, SCCT did not fully investigate the influence of media, especially the social media effects on the crisis communication; it still focused on the perspective of organizations and used the general term 'stakeholders' to describe the other key parties. Many of the above-mentioned theories and models failed to consider the impact of social media, which was changing the field of crisis communication by creating risks or crises and meanwhile bringing the interactive, dialogic and fast communication between the organization and stakeholders. The large amount of SMCM literature was discussing some new strategies and contexts, the interactive crisis response form, the stakeholder desired strategies on the Internet and the social media strategies on the recipients' perceptions of reputation. Within the SMCM research, organizations, social media, and stakeholders, as three major research perspectives, were clearly identified. Among these, the stakeholders and their media use have become the most dominant research perspective in the crisis communication, according to Chen (2016).

Researchers showed increasing interests towards the stakeholders and widely discussed motivation of social media use, emotions, identification and generated online contents during crises (Fortunato, 2011; Procopio, 2007; Stephens, 2009). Despite this common theoretical ground, in the last few years the SMCM literature provided two contradictory patterns in evaluating the effects of social media on the crisis communication. Some scholars were optimistic about the effective function of social media. For example, Kim and Liu (2012) found that social media was more frequently used than the traditional one in the organizational crisis management. through experimental analysis of the effects of CCS (i.e., information, sympathy and apology) via social media in comparison with traditional media, Schultz and Utz (2011) also found that the strategy of information on social media resulted in fewer negative crisis reactions than via traditional newspapers: newspapers might be credible to present issues, while Twitter had positive effects on secondary crisis communication (e.g., sharing and posting newspaper messages) and reactions (e.g., willingness to boycott). Meanwhile Brown has realized the empowering function of social media (2013) advising that organizations could effectively utilize the interactivity of social media, by creating dialogues with stakeholders, paying more attention to citizen-generated contents, adopting stakeholder desired strategies, cultivating opinion leaders on social media and creating texts, pictures or videos online in the same way for organizational legitimacy.

On the other hand, it was found that in crisis communication management methodologies social media might bring new challenges such as the image management issues, and fragmented media channels. A differentiation in CCM is also required in CCM according to the characteristics of the social media involved. For example, Gilpin (2010) found that image construction was nonlinear on social media, as each channel could address different dimensions of an organization's projected image. The ICC model also identified the contents between the organization and stakeholders. Through a reciprocal loop between them (Table 4), types of media and stakeholdergenerated contents (e.g., visual, text, voice messages or mix) on social media (e.g., Twitter, Pinterest, Facebook) were exchanged (Chen, 2016). Meanwhile, the organization continuously sends positive media contents to the public and maintains a good relationship. It is expected that the more positive the dialogue that an organization holds with its stakeholder, the more likely a high level of CCS effectiveness can be achieved if the prior reputation, relational characteristics with the public and situational variables are controlled. In the SMCM research, it was also found that the new 'digital' time frame of online media landscape has greatly shortened the length of time during which organizations were expected to react (Gilpin, 2010). Thus, controlling of the messages became more unpredictable on the social media than before. Social Media play a threefold role in crisis firstly they can be considered tools to manage communication crisis then they could amplify and increase the resonance of a crisis, and finally they could be the cause themselves of a crisis. 
Table 4. The interactive crisis communication model on social media (Chen, 2018)

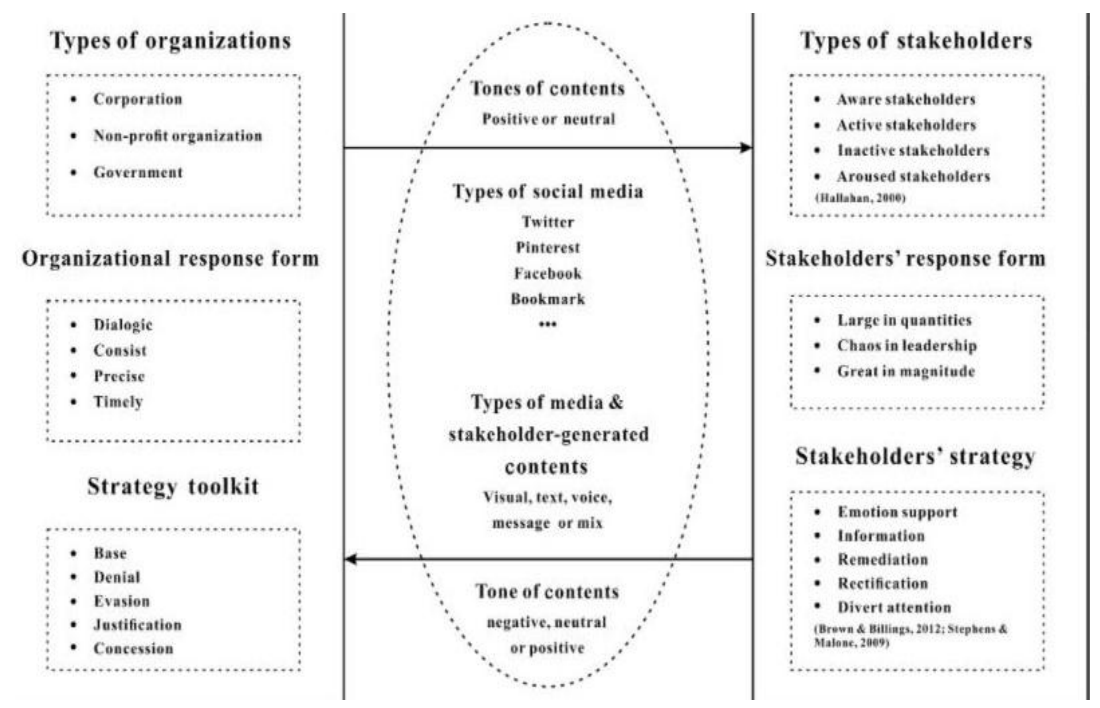

\section{Living in a Post-Truth Era}

\section{Post truth and Fake News}

In this paragraph we will discuss more in depth the process of constructing post-truths, understood as the rhetorical-persuasive strategies in which the subjective and emotional com- ponent prevails over the referential objective one (Oxford Dictionaries, 2016). In this definition, it is underlined that the prefix 'post' is meant to indicate not exactly the idea of past in a temporal sense but in the sense that truth has been eclipsed, therefore it is irrelevant. Fake news is the principle manifestation of post-truth phenomenon. the Cambridge Dictionary defines fake news as "false stories that appear to be news, spread on the internet or using other media, usually created to influence political views or as a joke"; a similar definition of the term in the Collins Dictionary (which declared "fake news" its word of the year for 2017, a year later) holds that it is "false, ofthen sensational, information disseminated under the guise of news reporting." Moreover, in this paragraph we analyse some of the most significant media phenomena that contribute to the strengthening and diffusion of post truth through social media, such as echo chambers, filter bubbles and the tendency towards political polarization within communicative exchanges through the activation of confirmatory bias on online platforms.

this phenomenon - strengthened by new media and their inherent viral cascading effect

- no longer assuming the objectivity of information as a reference parameter, uses pragmatic discursive procedures, associated with the production of meanings, that represent alternative truths often used as a weapon of delegitimization in political discourse (Baldi, 2018). the polysemic nature of the term post-truth inevitably widens the ground to analyse the phenomenon and the empirical data to be catalogued. Specifically, some significant meanings of post-truth are considered - being particularly functional for this research - such as the predominance of an emotional logic, the notion of post-truth as a pluralization from below of different versions of the facts that tend to undermine the credibility of the institutions intended as holders of official information and, above all, the concept of post-truth as rhetorical potential of communication also used for manipulative purposes. In today's era of instant information gratification, we have ready and unlimited access to opinions, rationalizations, and superficial descriptions which cause an informative overload. As Baldi suggests:

We can see in fake news a symptom of the crisis of the cognitive universe, of the beliefs and shared values of social groups. A new medium aimed at contrasting what is felt as the cultural, political, and scientific structure 
underlying power. In Italy, recent examples concern immigration or the issue of vaccines and now, of course, the situation related to Coronavirus. (Baldi, 20205)

McIntyre (2017) argued that some may wonder whether the idea of post-truth is really a new one. He tries to clarify that post truth is not just synonymous with propaganda and that 'alternative facts' are not merely falsehoods. As the issue is still not that simple, he goes further:

While there is some historical precedent for our current situation it would be wrong to try to reduce post-truth to something else. To say that facts are less important than feelings in shaping our beliefs about empirical matters seems new, at least in American politics. In the past we have faced serious challenges - even to the notion of truth itself - but never have such challenges been so openly embraced as a strategy for the political subordination of reality. thus, what is striking about the idea of post-truth is not just that truth is being challenged, but that it is being challenged as a mechanism for asserting political dominance. (McIntyre, 2017, p. 6)

The first step in fighting post-truth is to understand its genesis. the idea of post-truth does not simply emerge forcefully onto the scene in 2016 - as a result of Brexit and the US presidential election - but the phenomenon itself has deep roots that go back to the evolution of cognitive irrationalities that are shared by liberals and conservatives alike. McIntyre suggests that it also has roots in academic debates over the impossibility of objective truth that have been used to attack the authority of science. this formal attitude has been intensified by re- cent changes in the media landscape. Fueled by the rise of social media as a news source and a growing distrust of facts offered up by the establishment, post-truth as a concept has been finding its linguistic footing for some time. As a result, we assist daily to the explosion of science denial on trend topics like climate change, vaccines, evolution, Flat Earth, and the origin of COVID-19. the dramatically change of perspective of this very debate is that now everyone (who has a smartphone) can challenge the factual reality by telling her/his own truth. Fake news is frequently connected to politics and was famously thrust into the public eye in the run-up to the 2016 U.S. presidential elections, resulting in concerns about the influence of fake news on voters and elections in the United States. Furthermore, with the largely fact-free campaign over Brexit in Great Britain - where hundreds of buses advertised the bogus statistic that the UK was sending 350 million euros a week to the EU - and the growing use of disinformation campaigns by politicians against their own people in Hungary, Russia, and Turkey, many see post-truth as part of a growing international trend where some feel emboldened to try to bend reality to fit their opinions. Moreover, the infinite power of internet

is amplified in a worrying way by the total availability of social networks, accessible to all, which act as a sounding board for any thought that, once published, rises in the collective imagination to the value of truth. We are living the progressive triumph of pseudo-intellectuals without qualification, unspecified or disqualified for their very structure. (Baldi, 2018)

Science denial in general is relevant to understand the phenomenon of post-truth. Ac- cording to McIntyre (2018) it can start from either an economic or an ideological agenda. He deepens our understanding of this link between economic interests and post-truth politics, by considering how corporate-funded lobbying on a range of topics has influenced political positions on climate change, guns, immigration, health care, the national debt, voter reform, abortion, and gay marriage - in the U.S.

Global warming is perhaps the most egregious case of modern science denial. As noted, there are numerous booklength works on the charade of coordinated, manufactured scepticism to dispute the compelling scientific evidence for anthropogenic climate change. In a world where ideology trumps science, post-truth is the inevitable next step. (McIntyre, 2018)

${ }^{5} \mathrm{https} / / / \mathrm{www}$. lanazione.it/cronaca/il-coronavirus-infetta-anche-comunicazione-e-informazi- one-le-fake-news$1.5155972(06 / 2020)$. 
According to the results of the online survey - conducted by Edelman between 2012 and 2020 - about the trust in

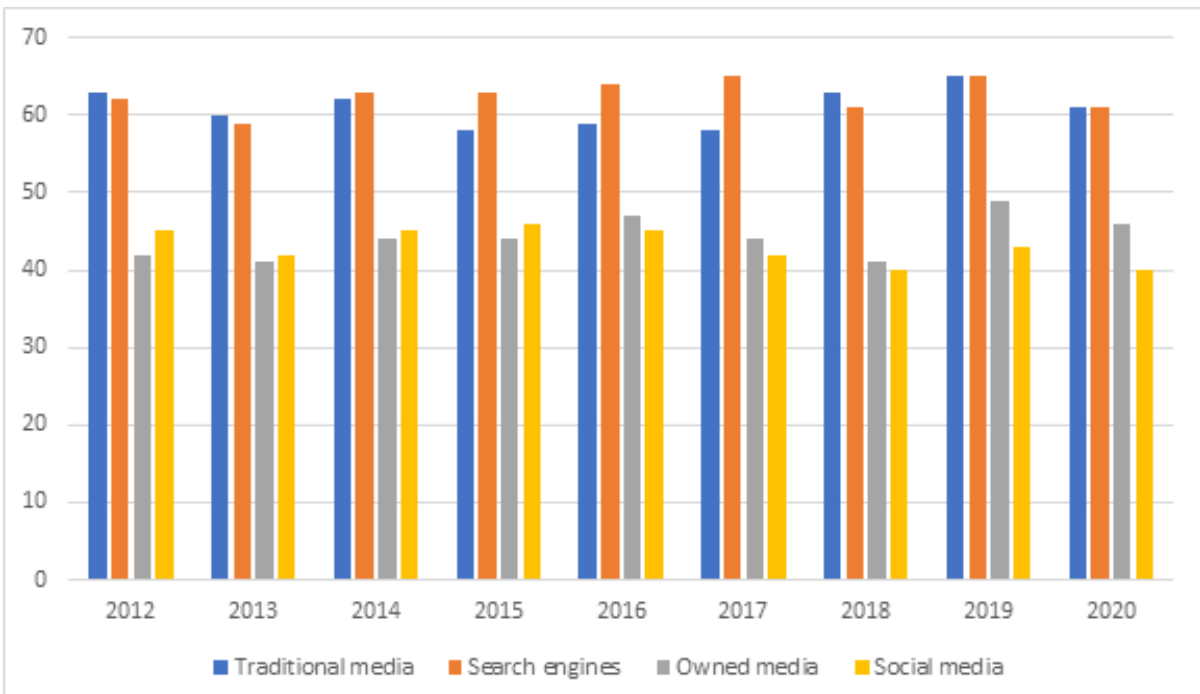

news on a global level, for general news and information, what emerges here is very interesting.

As of early 2020, 61 percent of adults who responded to a global survey stated that they trusted traditional media and search engines, making the two different but popular outlets the most trusted sources of news and information in the world. the source considered the least trustworthy was social media, not only on an overall global level but also in each world region. Social media was by far the least trusted news source in Europe and North America, and a sur- vey held in the United States revealed that most U.S. adults considered most of the news seen on social media to be biased. the reasons for news consumers' growing suspicions about the trustworthiness of media are multifaceted, but the onslaught of fake news is a major contributing factor. Adults in several countries worldwide have wrongly believed a news story was real until later realizing it was fake, and one of the top reasons for avoiding news was the inability to rely on its truthfulness. Conspiracy theories, tweets by politicians and poorly written or inaccurate news content often fall under the heading of fake news, and the term is also frequently used to describe news an individual disagrees with. As previously stated, fake news is not a recent phenomenon, and has historically been used to defame individuals, garner support for corrupt movements and portray minority groups in a negative way. this tactic of generating publicity by presenting false information as fact was utilized as a means of propaganda during the First and Second World Wars, and by the $21^{\text {st }}$ century became a major problem.

\section{Ideological Polarization and Echo Chambers, Filter Bubbles and Selective Exposure}

Ideological polarization has dominated both popular and academic debates over the past two decades. the discussion around polarization has gained increased attention in the face of the 2016 Presidential Election in the US and the 2016 EU Referendum in the UK, as previously mentioned in this article. Gentzkow (2016) observed in a recent paper on polarization around the US Presidential Election that clearly:

what divides them [Americans] politically is increasingly personal. We do not just disagree politely about what is the best way to reform the health care system. We believe that those on the other side are trying to destroy America.

It is important to note that while the examples of the US and recently the UK have been most vividly studied and discussed, similar patterns can be observed in Europe as well. Ideological polarization poses a threat to the healthy functioning of democratic societies. the most relevant consequence of polarization is a loss of diversity of opinions and arguments. Numerous studies have indicated that in polarized settings, "the benefit that ought to come with having a variety of opinions is lost to the righteousness that is the special entitlement of homogenous groups" 
(Bishop, 2008, p. 14). the consequences of this process are communities that effectively function as feedback loops or echo chambers, where we are "hearing our own thoughts about what's right and wrong bounced back to us by the television shows we watch, the newspapers and books we read, the blogs we visit online [...] and the neighbourhoods we live in" (Bishop, 2008, p. 39).

The functioning of the current news market and economics further perpetuates the polarization of news, but the area of popular concern has recently focused on exposure to ideological difference in online media. Social networks and online communication have considerably trans- formed political communication and public discourse. Over the past two decades, changes in communication technologies have affected the very nature of how citizens relate to each other and to their governments, shaping a new public sphere. As Brundidge notes, "the empirical support for increased exposure to political difference because of Internet use is somewhat limited and indirect" (Brundidge, 2010). the Internet and network platforms are especially likely to foster selective exposure behavior due to the inconceivably large amount of information that users are presented with all the time. Due to this information overload, platforms like Facebook are designed in a way that they facilitate consumers' ability to attend to the information selectively.

One of the two main arguments identifies the algorithms that curate online experiences as the source of the problem. Pariser (2011) has popularized the term filter bubble to illustrate this phenomenon of polarization on social media platforms like Facebook. He argues that algorithms which are intended to customize and personalize the user's online experience place the user in a bubble where he or she is only presented with information that matches with previous consumption behavior. the aim and function of these algorithms is to connect people with information they are likely to want to consume, by making some items easier to access than other items, resulting in a personalized stream of content that fails to offer users a set of alternatives to choose from (Rader and Gray, 2015, p. 175). Algorithmic curation and filters on Google or the Facebook News Feed are prediction engines, constantly creating and refining a theory of the identity of the users.

These engines create a unique universe of information for each of us which fundamentally alters the way we encounter ideas and information. A recent study of the effects of algorithmic curation on social networking services found empirical evidence that customizability technology increased ideologically driven selective exposure and the likelihood of echo chambers and filter bubbles in the modern media landscape. the study concludes that

due to its automatic and unobtrusive operation, customizability technology might be particularly effective at reducing cognitive dissonance associated with the avoidance of challenging information and, in contradiction with previous studies, showed that system-driven customizability (e.g. Facebook News Feed algorithm) had a stronger influence on selective exposure than user-driven customizability. (Dylko et al., 2002, p. 188)

According to Reuters Institute Digital News Report 2020, an increasing number of users tend to get their news on social media and use the platform for news consumption. As social media plays an increasing role in the consumption of news and information, the effects of ideological polarization in information consumption become arguably more apparent. In recent years, social networks have displayed symptoms of ideological polarization and the formation of the so-called filter bubbles. 


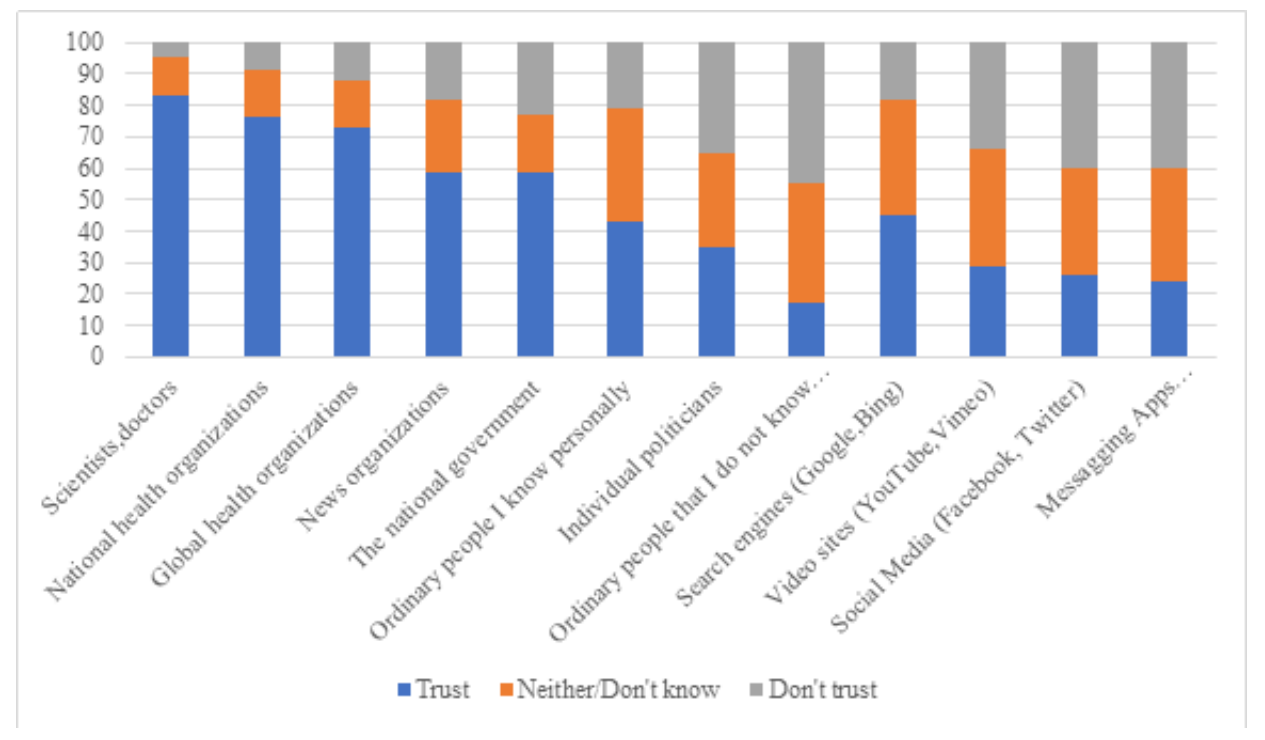

At around the peak of the lockdowns, trust in news organizations around COVID-19 was running at more than twice that for social media, video sites, and messaging applications where around four in ten see information as untrustworthy. By contrast information found in search engines was more reliable. Of course, neither search nor social companies create content themselves, so trust in this context reflects the selection decisions they make. It is particularly striking that average levels of trust in the national government and news organizations are almost identical, perhaps reflecting the way that in the early stages of this crisis many media organizations focused on amplifying government messages about health and social distancing, including carrying extended government press conferences. As things return to normal, the media are likely to become more critical of government and this may in turn lead to a return of more partisan approaches to media trust (Reuters Institute, 2020).

At around the peak of the lockdowns, trust in news organizations around COVID-19 was running at more than twice that for social media, video sites, and messaging applications where around four in ten see information as untrustworthy. By contrast information found in search engines was more reliable. Of course, neither search nor social companies create content themselves, so trust in this context reflects the selection decisions they make. It is particularly striking that average levels of trust in the national government and news organizations are almost identical, perhaps reflecting the way that in the early stages of this crisis many media organizations focused on amplifying government messages about health and social distancing, including carrying extended government press conferences. As things return to normal, the media are likely to become more critical of government and this may in turn lead to a return of more partisan approaches to media trust (Reuters Institute, 2020).

McIntyre suggests that there are two opposing arguments about the source of this growing ideological polarization in online media consumption. Some theorists claim that the algorithmic curation that filters our online experiences effectively places us in echo chambers of our own beliefs and is the strongest cause of polarization (Pariser, 2011; Rader and Grey, 2015) and a critical factor in the growing importance of fake news. the other source of polarization discussed has been around for much longer and has its roots in psychology and behavioral economics. By this argument, selective exposure behavior, confirmation bias and availability bias that make us more likely to interact with content which confirms our pre-existing views are assumably triggers of ideological polarization, both offline and online. 


\section{Psychological biases}

the second hypothesis attempting to specify the source of ideological polarization online focuses on the psychological biases of the user. Specifically, the phenomena that individuals tend to consume media which aligns with their views and beliefs and avoid such content that is different in perspective or even challenging their position. this phenomenon is called selective exposure, or sometimes partisan selective exposure, and there is increasing evidence to support the argument that selective exposure has a significant influence in polarization and group homogeneity. One of the supporters of the concept argued early on that 'the tendency of people to expose themselves to mass communications in accord with their existing opinions and interests and to avoid unsympathetic material, has been widely demonstrated' (Klapper, 1960, p. 19). the concept regains popularity today, as the present media landscape with its ever-growing variety of media outlets increases the potential for selective exposure. Recent research seems to support this argument. the psychological cause of selective exposure is a phenomenon which researchers call confirmation bias the 'seeking or interpreting of evidence in ways that are partial to existing beliefs, expectations, or a hypothesis in hand' (Nickerson, 1998, p. 175). It is important to note that such psychological processes can, and othen do, occur partially or entirely unaware. the human brain engages in the process of case-building as a result of its need for consistency and a desire to defend its beliefs, and this happens without a conscious intention of treating evidence from a biased perspective and individuals being somewhat unaware of this process (Nickerson, 1998). Numerous studies support this statement by finding that individuals tend to recall more information that is in favor of their position and evidence that confirms their hypothesis, so that they require less hypothesis confirming evidence to accept an idea than they need hypothesisinconsistent information to reject it. Furthermore, they also tend to have unfounded overconfidence in their knowledge and beliefs.

In a study of selective exposure to information, according to Frey (1986), individuals have the capability to increase the chances of getting information which confirms their existing beliefs. Consequentially the possibilities of encountering information that is inconsistent to what they believe decrease. this point needs to be stressed more than ever because the ability to filter information on a platform like Facebook is pervasively strong. People influenced by selective exposure - tend to organize their surroundings in a way that ensures selectivity. Scholars agree on the fact that the ways in which we encounter and process information are "first and foremost pragmatic, survival mechanisms and only secondarily truth detection strategies" (Friedrich, 1993, p.298) and that confirmation bias and belief perseverance, from a psychological and mental health perspective, might actually be helpful in protecting the consistency of thought and reduce vulnerability to errors (Nickerson, 1998, p. 208).

\section{Conclusions}

It is important at this point to give at least a minimal definition of truth. So far the most famous is Aristotle's definition, who said: "to say of what is that it is not, or of what is not that it is, is false, while to say of what is that it is, and of what is not that it is not, is true" (Aristotle, Metaphysics). The idea of a single objective truth has never been free from controversy. the concept of truth in philosophy traces its roots back to Plato, who warned through Socrates of the dangers of false claims to knowledge. Ignorance, Socrates felt, was remediable; if one is ignorant, one can be taught. Nevertheless, the greater threat comes from those who have the hubris to think that they already know the truth, for then one might be impetuous enough to act on a falsehood. Epistemologically speaking, this sort of correspondence is correct, whereby we judge the truth of a statement only by how well it fits reality. Other prominent conceptions of truth reflect a diversity of opinion among philosophers about the proper theory of truth, even while - as a value - there seems little dispute that truth is important. As previously mentioned, ignorance can be remediable because it is intended as an unintentional act but when we tell a falsehood with intent to deceive, we are lying. Every lie has an audience and when our intent is to manipulate someone into believing something that we know to be untrue, we have moved from the mere interpretation of facts into their falsification. McIntyre argues if that is what post-truth is about (McIntyre, 2017, p. 21). 
If we infer the intention to perpetrate falsification, the Gricean cooperative principles in pursuit of effective communication are deceived. Grice focuses his reflection on meaning starting from concrete conversational exchanges - which typically occur between two subjects, face to face, intent to communicate intentionally. Communication is conceived as an intentional production of effects and it can be understood only within a general theory of intentional and rational action: "what words mean is a matter of what people mean by them" (Grice, 1989, p. 340). The structural change of communication made possible by the very nature of the digital dimension of social media, and the narrative-subjective approach to the facts have undermined the epistemological basis of truth. The Coronavirus crisis has substantially increased news consumption for mainstream media before and ather the pandemic had taken effect. Television news and online sources have seen significant upticks, and more people identify television as their main source of news, providing temporary respite from a picture of steady decline. Consumption of printed newspapers has fallen as lockdowns undermine physical distribution, almost certainly accelerating the shith to an all-digital future. At the same time, the use of online and social media substantially increased in most countries. Global concerns about misinformation remain high. Even before the coronavirus crisis hit, more than half of global sample said they were concerned about what is true or false on the internet when it comes to news (Reuters Institute). Domestic politicians are the most frequently named source of misinformation, though in some countries people who self-identify as right-wing are more likely to blame the media - part of a 'pick-your-side' dynamic. Facebook is seen as the main channel for spreading false information almost everywhere. Political polarization linked to rising uncertainty seems to have undermined trust in public broadcasters, which are losing support from political partisans from both the right and the leth.

At the end of this discussion the main questions to focus on are: who is most exposed and vulnerable to its influence? Who is led or predisposed to believe in fake news? What are the possible defenses to the systemic alteration of truth? And, finally, is it still possible to talk about truth and reality? If so, how should we conceive of them? these questions summarize an extremely serious question raised by our analysis. It is worth noting that Grice's conversational maxims, which attempt to define the fundamental requirements for communicative cooperation, include: "do not say what you believe to be false" and "do not say that for which you lack adequate evidence" (Grice, 1993, p. 46). Grice knows as well as we do that there are infinite ways to contravene the teaching of these maxims and that their intentional or unintentional viola- tion is the norm rather than the exception. they are nonetheless pointing of reference without which communication could not exist. Credibility, which depends on interlocutors 'telling the truth,' is the necessary condition of every communicative relationship. No relationship is possible unless we trust the other to speak sensibly and tell the truth. this applies not only to quotidian relationships; for example, the credibility of a politician is based largely on whether he or she tells the truth (Maddalena and Gili, 2020). A significant portion of political rhetoric, both positive and negative, appeals to the trustworthiness of the speaker and to the related notion of 'sincerity,' which is the subjective dimension of credibility, the attitude others perceive in the person who 'wants' the truth. the credibility of journalism and of the media is also tied to their telling the truth and conducting the research necessary to do so. So, in this epoch of the weakening of the concepts of truth and reality that we have described, it is no wonder that counteroffensives have attempted to restore the idea of truth.

The paradox of the story we have told is that, ather having progressively eviscerated the power of communication to refer to reality, we now want to eliminate the possibility of multiple meanings, a possibility that has been pursued for so long, only to return to diminished and impoverished references to a merely numerical reality. Ather almost a hundred years, Lippmann's positivist diagnosis may be prevailing again: a reliable representation of social reality is only that which translates it into statistics of births, deaths, weddings, accidents, elections, and economic systems, consistent with the most reliable and definitive methods of knowledge known to science (Maddalena and Gili, 2020). When it comes to narrating and interpreting complex and controversial events, this diagnosis necessarily leads us to surrender to the fact that ideological prejudice, imperfections of language, and constraints in the information production process inexorably encase the real world in stereotypical visions which are to a greater or lesser extent deformed. this last example of negative consequences reverses the Nietzschean statement 'there are no more facts but only interpretations' to read: there are no interpretations, but only facts. 


\section{References}

Baldi, B. 2018. \#Opinione immediata. Opinione pubblica, post-verità e altre menzogne. Firenze: Pacini Editore.

Baldi, B. 2019. Complotti e raggiri: Verità, non verità, verità nascoste. Roma: Viella Libreria Editrice. Baldi, B. 2020. "Il Coronavirus 'infetta' anche comunicazione e informazione: le fake news." La Nazione. https://www.lanazione.it/cronaca/il-coronavirus-infetta-anche-comunicazione-e-infor-mazione-le-fake-news$1.5155972(06 / 2020)$.

Baldi, B.,Franco, L. and Savoia,L.M.2015. "(De)legitimization Strategies in the Austere Prose of Palmiro Togliatti.” QULSO 1: 139-158. DOI: http://dx.doi.org/10.13128/QULSO-2421-7220-16520.

Baldi, B.,Franco, L. and Savoia,L.M. 2019. "Alternative Truths and Delegitimization Pragmatic Strategies Around the 2018 Italian Elections." Journal of Language Aggression and Conflict 7, 2: 293-320.

Baldi, B., and Savoia, L.M.2009. "Metafora e ideologia nel linguaggio politico." Lingua italiana d'oggi 6: 119165.

Baldi, B., and Savoia, L.M. 2017. "L'identità come mezzo di (de)legittimazione: procedure linguistiche e pragmatiche nel discorso politico." In La delegittimazione politica nell'età contempo- ranea 2. Parole nemiche: teorie, pratiche e linguaggi, ed. by Benedetta Baldi, 287-338. Roma: Viella Libreria Editrice.

Bauman, Z. 2003. City of Fears, City of Hopes. London: Goldsmiths College. Bauman, Zygmunt. 2009. Paura liquida. Roma-Bari: Laterza.

Bauman, Z. 2000. Liquid Modernity. Cambridge: Polity Press. Bauman, Zygmunt, and Carlo Bordoni. 2014. Stato di crisi. Bologna: Einaudi.

Bianchi, C. 2009. Pragmatica cognitiva. I meccanismi della comunicazione. Bari: Laterza.

Brown, A. 2013. "Sports Fans as Crisis Communicators on Social Media Websites." Public Relations Review 39, 1: 74-81.

Caiani, M. 2011. "L'estrema destra in Italia fra passato e presente: il discorso sulla globalizzazione in Societa." Mutamento e Politica 2: 133-151.

Caiani, M. and Della Porta, D. 2011. "the Elitist Populism of the Extreme Right: a Frame Analysis of Extreme Right Wing Discourses in Italy and Germany." Acta Politica 46, 2: 180-202.

Calise, M., and Musella F. 2019. Il principe digitale. Bari: Laterza.

Castells, M. 1996. The Rise of the Network Society. Cambridge: Blackwell Publisher.

Castells, M. 2012. Reti di indignazione e di speranza. Movimenti sociali nell'era di Internet. Milano: Università Bocconi Editore.

Castells, M. and Himanen P. 2014. Reconceptualizating Development in the Global Information Age. Oxford: Oxford UP.

Chen, Y. 2016. "How Social Media Is Changing Crisis Communication Strategies: Evidence from the Updated Literature." Journal of Contingencies and Crisis Management, 26, 1: 58-68

Collins Dictionary. 〈https://www.collinsdictionary.com/it/dizionario/inglese/fake-news.

Coombs, T. 2007. "Protecting Organization Reputations During a Crisis: the Development and Application of Situational Crisis Communication theory." Corporate Reputation Review, 10, 3: 163-176.

Coombs, T. 2014a. "Applied Crisis Communication and Crisis Management: Cases and Exercises." In Sage, thousand Oaks, CA. Ed.by Sage Publications, 104-146.

Coombs, T. 2014b. "State of Crisis Communication: Evidence and the Bleeding Edge." Research Journal of the Institute for Public Relations, 1, 1:1-12.

Coombs, T. 2015. Ongoing Crisis Communication: Planning, Managing and Responding. thousand Oaks: Sage.

Crocchi, S.C. 2019. "Corporate Storytelling as an Effective Communication Tool.” QULSO, 5: 431-458.

DOI: http://dx.doi.org/10.13128/QULSO-2421-7220-25976 
Crocchi, S.C. 2020. "Corporate Storytelling." In Comunicare ad arte per costruire contenuti e promuovere eventi, ed. by Benedetta Baldi, 237-257. Firenze: Zanichelli.

Dylko I. and Dolgovb I., et al. 2017. "the Dark Side of Technology: An Experi- mental Investigation of the Influence of Customizability Technology on Online Political Selective Exposure." Computers in Human Behavior 73: 181-190.

Fearn- Banks, Kat. 2011. Crisis Communications: A Casebook Approach. New York: Routledge. Ferraris, Maurizio. 2017. Postverità e altri enigmi. Bologna: Il Mulino.

Fortunato, J. (2011). "Dancing in the Dark: Ticketmaster's Response to its Bruce Springsteen Ticket Crisis." Public Relations Review, 37, 1: 77-79.

Freberg, K. 2012. "Intention to Comply with Crisis Messages Communicated via Social Media."Public Relations Review, 38, 3: 416-421.

Gilpin, D. 2010. "Organizational Image Construction in a Fragmented Online Media Environment.”Journal of Public Relations Research, 22, 3: 265-287.

Goffman, E.. 1959. The Presentation of Self in Everyday Life. Edinburgh: University of Edinburgh, Social Sciences Research Centre.

Grice. H.P. 1993. "Logica e conversazione.” In Logica e conversazione. Saggi su intenzione, significato e comunicazione, ed. by Giorgio Moro, 55-76. Bologna: Il Mulino.

Jackendoff, R. 2002. Foundations of Language. Brain, Meaning, Grammar, Evolution. Oxford: Oxford UP.

Kaplan A.M., and Haenlein M. 2010. "Users of the world, unite! the Challenges and Opportunities of Social Media." Bus Horiz 53, 1: 59-68.

Klapper, J.T. 1960. The Effects of Mass Communication. New York: Free Press.

Kim, S. and Brooke, L. 2012. "Are All Crises Opportunities? A Comparison of How Corporate and Government Organizations Responded to the 2009 Flu Pandemic.” Journal of Public Relations Research, 24, 1: 69-85.

Lapper, J. 1960. The Effects of Mass Communication. Glencoe: the Free Press.

Lakoff, G. 1972. "Structural Complexity in Fairy Tales." In The Study of Man, vol. I, Presented at the Summer Meeting of the Linguistic Society of America, 128-150.

Lakoff, G. 1996. Moral Politics. Chicago: University of Chicago Press. Lakoff, George. 2008. The Political Mind. New York: Viking Penguin.

Lakoff, G. 2016. Understanding Trump, online in Political. <https://georgelakoff.com/2016/07/23/ understandingtrump-06/2020> (06/2020).

Lakoff, G. and Johnson M. 1980. Metaphors We Live By. Chicago: University of Chicago Press.

Lakoff, G. and Johnson M. 1999. Philosophy in the Flesh: The Embodied Mind and Its Challenge to Western Thought. New York: Basic Books.

Lazarsfeld, P. 1948. The People's Choice. New York: Columbia UP.

Levitsky, S. and Ziblatt D. 2018. How Democracies Die. New York: Penguin Random House. Lippman, W. 2004. L'opinione pubblica. Roma: Donzelli Editore.

Maddalena, G. 2015. The Philosophy of Gesture. Montreal: McGill-Queen's UP.

Maddalena, G. and Gili G. 2020. The History and Theory of Post-Truth Communication Springer International Publishing. Cham: Palgrave Macmillan.

McIntyre, L. 2015. Respecting Truth: Willful Ignorance in the Internet Age. New York: Routledge Pub- lishers.

McIntyre, L. 2018. Post-Truth. Cambridge: MIT Press.

Mumford, L. 1956. The Transformations of Man. New York: Harper.

Nickerson, R. 1998. "Confirmation Bias: A Ubiquitous Phenomenon in Many Guises." Review of General Psychology 2, 2: 175-220. 
Oxford Dictionary. 2016. <https://www.oxfordlearnersdictionaries.com/definition/english/post-truth>. Palese, Emma. 2013. "Zygmunt Bauman. Individual and society in the liquid modernity.” SpringerPlus,2, 191.

Pariser, E. 2011. The Filter Bubble: What the Internet is Hiding from You. New York: Penguin Group. Pearson, Christine and Ian Mitroff. 1993. "From Crisis Prone to Crisis Prepared: A Framework for Crisis Management." Academy of Management Executive, 7, 1: 48-59.

Petrosino, S. 2008. L'esperienza della parola. Testo, moralità e scrittura. Milano: Vita e Pensiero. Procopio, Serena. 2007. "Do You Know What It Means to Miss New Orleans? Internet Communication,

Geographic Community, and Social Capital in Crisis." Journal of Applied Communication Research, 35, 1: 6787.

Rader,E. 2015. "Understanding User Believes about Algorithmic Curation in the Facebook News Feed." In Proceedings of the 33rd Annual ACM Conference on Human Factors in Computing Systems, Begole Ben and Kim Jaegwon (eds), Seoul, Republic of Korea, 18-23 April 2015, 173-182. New York: ACM.

Reuters Institute. 2019. http://www.digitalnewsreport.org/survey/2019/.

Reuters $\quad$ Institute. $2020 . \quad$ https://reutersinstitute.politics.ox.ac.uk/sites/default/files/2020-06/ DNR_2020_FINAL.pdf.

Schulz, F. 2011. "Is the Medium the Message? Perceptions of and Reactions to Crisis Communication via Twitter, Blogs and Traditional Media.” Public Relations Review, 37, 1: 20-27. Schultz, Majken, J.M. Hatch, and Holten Larsen. 2000. The Expressive Organization: Linking Identity,Reputation and Corporate Brand. Oxford: Oxford UP.

Statista.2020. https://www.statista.com/statistics/1106498/home-media-consumption-coronavirus-worldwideby-country/

Van Riel, C. 1995. Principles of Corporate Communication. Harlow: Pearson Education Limited.

Volli, U. 2008. Lezioni di filosofia della comunicazione. Roma: Editori Laterza.

Wicke, P. 2020. "Framing COVID-19: How we conceptualize and discuss the pandemic on Twitter." In Computation and Language (cs.CL), Social and Information Networks, https://arxiv.org/abs/2004.06986> $(06 / 2020)$. 